\section{Gender and incidence of functional disability in the elderly: a systematic review}

\author{
Gênero e incidência de incapacidade funcional \\ em idosos: revisão sistemática
}

\author{
1 Programa de Pós-graduação \\ em Epidemiologia \\ Universidade Federal de \\ Pelotas, Pelotas, Brasil. \\ Correspondence \\ M. A. P. Rodrigues \\ Programa de Pós-graduação \\ em Epidemiologia, \\ Universidade Federal \\ de Pelotas. \\ Rua Marechal Deodoro 1160, \\ 3 o andar, Pelotas, $R S$ \\ 96020-220, Brasil. \\ rodriguesmapa@terra.com.br
}

\author{
Maria Aparecida Pinheiro Rodrigues 1 \\ Luiz Augusto Facchini 1 \\ Elaine Thumé 1 \\ Fátima Maia 1
}

\section{Introduction}

This systematic review aimed to assess the effect of gender on the incidence of functional disability in the elderly. The search for publications in the MEDLINE, EMBASE, and ProQuest electronic databases from January 1990 to March 2008 identified 879 publications, from which 21 cohort studies were selected that evaluated gender as an independent variable and incidence of functional disability in elderly as the outcome. Review of the studies found that after adjusting for socioeconomic, health, and social relations indicators, incidence of functional disability was similar between genders. The main risk factors for functional disability in the elderly, regardless of gender, were: lack of schooling, living in rental housing, chronic diseases, arthritis, diabetes, visual impairment, body mass index above 25 , poor self-perceived health, cognitive impairment, depression, slow gait, sedentary lifestyle, tiredness while performing daily activities, and limited diversity in social relations.

Disabled Health; Frail Elderly; Gender and Health
Functional disability is an important health indicator in the elderly, jeopardizing quality of life and causing heavy social impact with long-term institutionalization and increased use of medical care 1.

To reduce functional disability - a major challenge for public health - requires knowledge of the risk factors involved in the process loss of autonomy by the elderly in order to allow efficient preventive strategies. In this context, it is necessary to determine the role of gender in the incidence of functional disability in the elderly, in order to establish preventive measures, and the healthcare supply needs to be adjusted for men and women.

The higher prevalence of functional disability in women has been attributed mainly to greater female longevity 2,3 , but a study that replaced female mortality rates with male mortality rates observed a greater impact in the survival difference than in the difference between the genders in prevalence of functional disability 4 , suggesting the possibility of higher incidence of functional disability among elderly women as compared to men. Meanwhile, research on the incidence of functional disability in elderly men and women has shown conflicting results, with some studies indicating higher incidence in women 4,5 , others in men ${ }^{6}$, and still others with no difference between the genders $7,8,9$. 
The aim of this systematic review was to verify whether functional disability risk factors and incidence vary according to gender in the elderly, to help ensure adequate planning of public policies for the prevention of functional limitations and organization of health services.

\section{Methods}

\section{Definition of functional disability}

The definition of disability encompasses various aspects. Illness, impairment, limitation, and handicap are terms that are directly associated with the concept of disability. Functional disability in the elderly is defined as an acquired difficulty in performing basic everyday tasks or more complex tasks needed for independent living 10 . Performance in functional disability includes three dimensions: physical, emotional, and mental 11. Physical performance relates to the body's sensory and motor function, and is evaluated through activities like walking, crouching, and running. Emotional performance is measured through the individuals' adaptation to various events in their lives. Mental performance is evaluated through tests that measure the individuals' intellectual and rational capacity. The current review study covered only the physical dimension of functional disability.

Sometheoreticalmodels have been developed with the aim of explaining these concepts, facilitating knowledge, and understanding the terms used and backing their applicability in research, public policies, and clinical practice $8,12,13$. The model adopted by the World Health Organization (WHO) in 2001 combines a biological, individual, and social perspective, establishing a standardized language to describe functional status according to the individual's health conditions. According to this definition, functionality encompasses all body functions, tasks, or actions, and disability includes impairment, limited capacity, or restricted performance of activities 12,13.

The most widely used measurements of functional disability in the literature are those that assess basic activities of daily living, instrumental activities of daily living, and mobility. These indicators can be evaluated by means of the degree of difficulty (no difficulty, little difficulty, great difficulty, incapable of performing the task or activity) and/or dependence (need for help from others or inability to perform a task). The most frequently used indicator for measuring basic activities of daily living is the scale developed by Katz \& Akpom 14 , according to which the elderly lose the capacity to perform tasks in the inverse order that they acquire them in childhood. Basic activities of daily living include self-care tasks, which in the most famous version includes six items: bathing, getting dressed, going to the bathroom, getting from bed to a chair and vice-versa, maintaining sphincter continence, and eating. Instrumental activities of daily living are more adaptive tasks, necessary for independent living in the community, whose most widely used scale is that developed by Lawton \& Brody 15 , with eight items: using the telephone, shopping, cooking one's own meals, housecleaning, laundry, using transportation, taking medication, and managing finances. The evaluation of mobility refers to tasks related to the individual's locomotor system and that are measured through various instruments. The selected studies used the following instruments, although partially: Rosow-Breslau 16 (three items: walking $800 \mathrm{~m}$; climbing stairs; and performing heavy work around the home), Nagi 11 (five items: stooping, crouching, or kneeling; pulling or pushing an object like an armchair; raising one's arms above the shoulders; writing or holding small objects; and carrying more than 5kg), Mobility-Help Scale 17 (six items: need for help to get from bed to a chair; walking inside the home; going out; walking on the street in good weather; walking on the street in bad weather; and climbing stairs). There are also instruments that combine various items from basic activities of daily living, instrumental activities of daily living, and mobility: the Stanford Health Assessment Questionnaire 18, which measures functional disability through 20 items subdivided into eight categories (getting dressed; getting up; eating; walking; personal hygiene; reaching objects; grasping objects; and mobility outside the home) and the instrument of the Office for National Statistics 19, from the United Kingdom, which measures functional disability through 13 items (locomotion; flexibility; dexterity; grooming; sight; hearing; continence; communication; awareness; behavior; intellectual function; digestion; and overall status).

\section{Sources}

The published studies were identified through the MEDLINE/PubMed, EMBASE, and ProQuest databases from January 1990 to March 2008. The terms used were "elderly", "aged", "older ones", "disability”, “impairment”, “decline”, or "limitation" combined with "functional" and "longitudinal studies" for defining the outcome. The modifiers used were "risk", "gender differences", "activities of daily living", and "health status". The references from articles included in this study were reviewed. Review studies, unpublished articles, abstracts, theses, dissertations, 
and book chapters were not included. The review only included studies in English, Spanish, or Portuguese.

\section{Study selection}

The review included cohort studies published from January 1990 to March 2008, performed in individuals 55 years or older, living in the community, where the outcome was incidence of functional disability and in which gender was evaluated as an independent variable or the analyses were stratified by gender. Figure 1 summarizes the exclusion process for the retrieved studies. Of the 879 initially identified studies,
78 were excluded because they failed to present original results. Next, 232 studies were excluded because the measures of disability failed to meet the current review's criteria. Another 182 studies were then excluded because the samples consisted partially or totally of institutionalized elderly. Lack of quantitative data analysis was cause for exclusion of 104 studies. Next, 236 cross-sectional studies were excluded. Finally, 26 studies were excluded that only evaluated changes in the degree of functional disability as the outcome, leaving 21 studies that analyzed incidence of functional disability in elderly who did not present functional limitations at the start of follow-up.

Figure 1

Diagram of study selection.

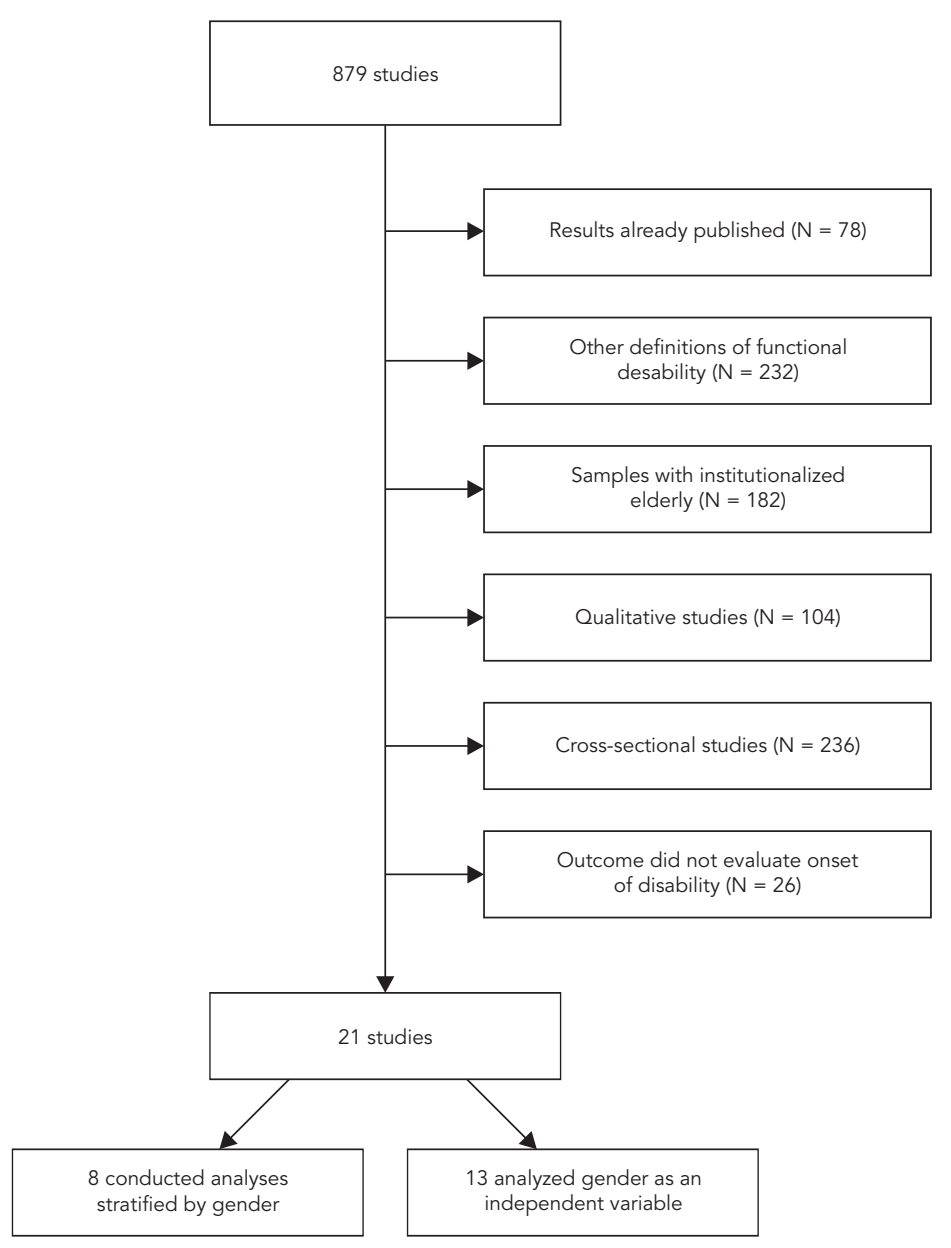




\section{Evaluation of studies}

The methodological quality of the selected studies was evaluated by applying the Downs \& Black criteria 20 , which analyzed data quality, internal validity, and external validity in the studies through 19 items, with a maximum score of 20 .

The main characteristics of the studies were described: country in which the study was performed, principal author, year of publication, duration of study follow-up, measure(s) of disability used, sample size, baseline age, percentage of women, percentage of losses to follow-up, number of interviews performed, and Downs \& Black score. Two independent reviewers evaluated the studies' methodological quality and other characteristics listed in Table 1. When there was disagreement between the evaluations, a third reviewer evaluated the study and the final decision was made by consensus between the three reviewers.

In the 21 selected studies, 30 analyses of incidence of functional disability were performed. To investigate the cause of the different results in incidence rates for functional disability between genders in the elderly according to the analyses in the selected studies, they were divided according to the measures of disability used (basic activities of daily living, instrumental activities of daily living, and mobility) and according to adjustment of the respective analyses (crude, age-adjusted, and multivariate).

Risk factors for functional disability were defined as those evaluated through multivariate analyses and that showed a statistically significant association with higher incidence of functional disability in two or more analyses in the selected studies.

\section{Results}

\section{Description of studies}

A total of 879 articles were identified for review according to this review study's inclusion and exclusion criteria.

Table 1 provides a list of the 21 selected studies, in chronological order of publication. The studies were based on cohorts from the United States 4,5,7,8,21,22,23,24,25,26,27,28,29,30, United Kingdom 6,31, Netherlands 9 , Taiwan ${ }^{32}$, Denmark

Characteristics of cohort studies that evaluated incidence of functional disability according to gender in the elderly $(\mathrm{N}=21)$.

\begin{tabular}{|c|c|c|c|c|c|c|c|c|c|}
\hline $\begin{array}{l}\text { Country/ } \\
\text { Cohort }\end{array}$ & $\begin{array}{c}\text { Reference/ } \\
\text { Year }\end{array}$ & $\begin{array}{l}\text { Duration } \\
\text { of study } \\
\text { (months) }\end{array}$ & $\begin{array}{l}\text { Measure of } \\
\text { disability } \\
\text { (no. items) }\end{array}$ & $\begin{array}{l}\text { Sample } \\
\text { size }\end{array}$ & $\begin{array}{c}\text { Baseline } \\
\text { age (years) }\end{array}$ & $\begin{array}{l}\text { Percentage } \\
\text { of women }\end{array}$ & $\begin{array}{l}\text { Losses to } \\
\text { follow-up } \\
\text { (\%) }\end{array}$ & Interviews & $\begin{array}{l}\text { Downs } \\
\text { \& Black } \\
\text { score 20 } \\
\text { (max. 20) }\end{array}$ \\
\hline $\begin{array}{l}\text { USA, } \\
\text { Alameda } \\
\text { County }\end{array}$ & $\begin{array}{l}\text { Strawbridge } \\
\text { et al. } 8 / 1992\end{array}$ & 72 & $\begin{array}{c}\text { Basic activities } \\
\text { of daily living (7); } \\
\text { Mobility (2) }\end{array}$ & 508 & $65+$ & 59 & 5 & 2 & 16 \\
\hline USA, EPESE & $\begin{array}{l}\text { Bruce et } \\
\text { al. } 21 / 1994\end{array}$ & 30 & $\begin{array}{c}\text { Basic activities of } \\
\text { daily living (7) }\end{array}$ & 1,189 & $70+$ & 52 & 6 & 2 & 16 \\
\hline USA, EPESE & $\begin{array}{l}\text { Moritz et } \\
\text { al. } 28 / 1995\end{array}$ & 36 & $\begin{array}{c}\text { Basic activities of } \\
\text { daily living (7) }\end{array}$ & 1,856 & $65+$ & 58 & 13 & 5 & 18 \\
\hline USA, EPESE & $\begin{array}{l}\text { Beckett at } \\
\text { al. 5/1996 }\end{array}$ & 72 & $\begin{array}{c}\text { Basic activities } \\
\text { of daily living (6); } \\
\text { Mobility (7) }\end{array}$ & 14,904 & $65+$ & $\begin{array}{c}\text { Not } \\
\text { specified }\end{array}$ & 16 & 6 & 13 \\
\hline USA, EPESE & $\begin{array}{l}\text { Ferucci et } \\
\text { al. } 24 / 1996\end{array}$ & 84 & $\begin{array}{c}\text { Basic activities of } \\
\text { daily living (6) }\end{array}$ & 6,640 & $69+$ & 64 & 9 & 7 & 15 \\
\hline USA, LSOA & $\begin{array}{l}\text { Dunlop et } \\
\text { al. } 22 / 1997\end{array}$ & 72 & $\begin{array}{c}\text { Basic activities of } \\
\text { daily } \\
\text { living (6) }\end{array}$ & 2,777 & $70+$ & 59 & 17 & 4 & 14 \\
\hline USA & $\begin{array}{c}\text { Peek \& } \\
\text { Coward 30/ } \\
1999\end{array}$ & 30 & $\begin{array}{l}\text { Basic activities of } \\
\text { daily living (6); } \\
\text { Instrumental } \\
\text { activities of daily } \\
\text { living (4) }\end{array}$ & 749 & $65+$ & 79 & 9 & 5 & 15 \\
\hline USA & $\begin{array}{l}\text { Oman et } \\
\text { al. } 7 / 999\end{array}$ & 48 & Mobility (1) & 1,982 & $55+$ & 57 & 14 & 2 & 19 \\
\hline
\end{tabular}

(continues) 


\begin{tabular}{|c|c|c|c|c|c|c|c|c|c|}
\hline $\begin{array}{l}\text { Country/ } \\
\text { Cohort }\end{array}$ & $\begin{array}{c}\text { Reference/ } \\
\text { Year }\end{array}$ & $\begin{array}{l}\text { Duration } \\
\text { of study } \\
\text { (months) }\end{array}$ & $\begin{array}{l}\text { Measure of } \\
\text { disability } \\
\text { (no. items) }\end{array}$ & $\begin{array}{l}\text { Sample } \\
\text { size }\end{array}$ & $\begin{array}{l}\text { Baseline } \\
\text { age (years) }\end{array}$ & $\begin{array}{l}\text { Percentage } \\
\text { of women }\end{array}$ & $\begin{array}{l}\text { Losses to } \\
\text { follow-up } \\
\text { (\%) }\end{array}$ & Interviews & $\begin{array}{l}\text { Downs } \\
\text { \& Black } \\
\text { score 20 } \\
\text { (max. 20) }\end{array}$ \\
\hline $\begin{array}{l}\text { United } \\
\text { Kingdom }\end{array}$ & $\begin{array}{l}\text { Grundy \& } \\
\text { Glaser 6/ } \\
2000\end{array}$ & 66 & $\begin{array}{l}\text { Basic activities } \\
\text { of daily living (2); } \\
\text { Mobility (3) }\end{array}$ & 2,717 & $55+$ & 54 & 26 & 2 & 15 \\
\hline USA, EPESE & $\begin{array}{l}\text { Leveille et } \\
\text { al. } 4 / 2000\end{array}$ & 84 & Mobility (2) & 10,100 & $65+$ & 61 & 2 & 8 & 15 \\
\hline $\begin{array}{l}\text { United } \\
\text { Kingdom }\end{array}$ & $\begin{array}{l}\text { Jagger et } \\
\text { al. } 31 / 2001\end{array}$ & 70 & $\begin{array}{c}\text { Basic activities of } \\
\text { daily living (7) }\end{array}$ & 1,344 & $75+$ & 59 & 20 & 5 & 15 \\
\hline USA, EPESE & $\begin{array}{l}\text { Melzer et } \\
\text { al. } 27 / 2001\end{array}$ & 84 & Mobility (2) & 8,871 & $65+$ & 60 & 5 & 8 & 15 \\
\hline USA, LSOA & $\begin{array}{l}\text { Dunlop et } \\
\text { al. } 23 / 2002\end{array}$ & 72 & $\begin{array}{c}\text { Basic activities of } \\
\text { daily living (7) }\end{array}$ & 4,205 & $70+$ & 67 & 13 & 4 & 16 \\
\hline $\begin{array}{l}\text { Denmark } \\
\text { and } \\
\text { Finland, } \\
\text { NORA }\end{array}$ & $\begin{array}{l}\text { Avlund et } \\
\text { al. } 33 / 2002\end{array}$ & 60 & $\begin{array}{l}\text { Basic activities } \\
\text { of daily living (8); } \\
\text { Mobility (3) }\end{array}$ & 517 & $75+$ & 62 & 8 & 2 & 15 \\
\hline USA & $\begin{array}{l}\text { Gill et } \\
\text { al. 25/2004 }\end{array}$ & 36 & $\begin{array}{c}\text { Basic activities of } \\
\text { daily living (4) }\end{array}$ & 344 & $70+$ & 65 & 4 & 36 & 17 \\
\hline Taiwan & $\begin{array}{l}\text { Chiu et } \\
\text { al. } 32 / 2004\end{array}$ & 48 & $\begin{array}{l}\text { Basic activities } \\
\text { of daily living } \\
\text { (7); Instrumental } \\
\text { activities of daily } \\
\text { living (8) }\end{array}$ & 903 & $65+$ & 50 & 4 & 2 & 15 \\
\hline $\begin{array}{l}\text { Denmark, } \\
\text { DISPHV }\end{array}$ & $\begin{array}{l}\text { Avlund et } \\
\text { al. } 34 / 2004\end{array}$ & 18 & Mobility (6) & 1,396 & $75+$ & 52 & 4 & 2 & 18 \\
\hline USA & $\begin{array}{l}\text { Murtagh \& } \\
\text { Hubert 29/ } \\
2004\end{array}$ & 156 & $\begin{array}{l}\text { Basic activities } \\
\text { of daily living } \\
\text { (3); Instrumental } \\
\text { activities of daily } \\
\text { living (3); Mobility } \\
\text { (2) }\end{array}$ & 1,348 & $60+$ & 23 & Ignored & 13 & 15 \\
\hline Netherlands & $\begin{array}{l}\text { Tas et } \\
\text { al. 9/2007 }\end{array}$ & 72 & $\begin{array}{l}\text { Basic activities } \\
\text { of daily living (3); } \\
\text { Mobility (5) }\end{array}$ & 3,642 & $55+$ & 59 & 15 & 3 & 19 \\
\hline USA & $\begin{array}{l}\text { Hardy et } \\
\text { al. 26/2008 }\end{array}$ & 72 & $\begin{array}{l}\text { Basic activities of } \\
\text { daily living (4) }\end{array}$ & 754 & $70+$ & 65 & 4 & 72 & 15 \\
\hline $\begin{array}{l}\text { Denmark, } \\
\text { DISPHV }\end{array}$ & $\begin{array}{l}\text { Nilsson et } \\
\text { al. } 35 / 2008\end{array}$ & 54 & Mobility (6) & 2,533 & $74+$ & 56 & 3 & 4 & 19 \\
\hline
\end{tabular}

EPESE: Established Populations for Epidemiologic Studies of the Elderly; LSOA: Longitudinal Study of Aging; NORA: Nordic Research on Ageing; DISPHV: Danish Intervention Study on Preventive Home Visits.

33,34,35, and Finland 33 (one study was based on a sample of elderly individuals from both Denmark and Finland). Duration of follow-up ranged from 18 to 156 months. Definition of functional disability varied according to degree of disability, number of items used in each scale, and cutoff point used in each scale. Thirteen studies used a single measure of functional disability 4,7,21,22, $23,24,25,26,27,28,31,34,35$ and the other eight studies used two to three measures of functional disability 5,6,8,9,29,30,32,33, resulting in 30 analyses of functional disability. The study's sample size was defined as that used in the data analyses and ranged from 344 to 14,904 individuals. Baseline age var- ied from 55 to 75 years. The percentage of women in the samples varied from 23 to $67 \%$, while one study 5 failed to specify the percentage of women in the sample. The percentage of losses ranged from 8 to $26 \%$, although one study 29 failed to provide the number of losses to follow-up. All the selected studies evaluated the functional condition of individuals in the sample at baseline, and those that already presented functional disability were excluded from the analyses. Evaluation of the studies' quality based on the Downs \& Black criteria 20 for non-intervention studies ranged from 13 to 19, with a maximum possible score of 20 points. The principal causes of loss of points in 
the studies were failure to describe the characteristics of losses to follow-up and random variation in the main findings.

Table 2 shows the results for incidence of functional disability according to gender in the elderly and the measure of disability used. As shown in this Table, functional disability in basic activities of daily living was evaluated in 14 studies $5,8,21,22,23,24,25,26,28,29,30,31,32,33$. Of these, two observed higher incidence of functional disability in women 5,22 and 12 found no difference in the incidence between genders 8,21,23,24,25,26, $28,29,30,31,32,33$. Disability in instrumental activities of daily living was examined in three studies 29,30,32; one found a higher incidence of functional disability in women 30 and two found no difference in incidence between the genders 29,32. Mobility disability was evaluated in nine studies $4,5,7,8,27,29,33,34,35$, four of which 4,5,34,35 observed higher incidence of functional disability in women, while five 7,8,27,29,33 found no difference in incidence between genders. Three studies used instruments that combined two to three measures of functional disability 6,9,30. One found higher incidence of functional disability in women ${ }^{9}$, another found higher incidence in men ${ }^{6}$, and the third found no difference in incidence between the genders 30 .

Table 3 shows the results for incidence of functional disability according to gender, based on measure of disability and adjustment of the analysis (crude or multivariate). Of the 21 studies
4,5,6,7,8,9,21,22,23,28,29,30,31,32,33,34,35, twelve 6,7,21,23,25, 26,27,28,29,30,32,33 conducted 18 analyses adjusted for multiple factors when analyzing incidence of functional disability. One found higher incidence of functional disability in instrumental activities of daily living in women, another found higher incidence for basic activities of daily living and mobility in men, and the others found no differences between the genders in the incidence of functional disability. The other nine studies 4,5,8, 9,22,24,31,34,35 conducted 12 analyses adjusted for one or two factors, of which eight identified higher incidence of functional disability in women and four found no difference in incidence between the genders.

\section{Risk factors for functional disability}

Table 4 describes the risk factors for functional disability in at least two of the selected studies that performed adjusted analyses. Studies that performed gender-stratified analyses 9,21,27,28,29,34 allowed observing whether risks for functional disability differ between men and women.

Increasing age was the most frequent risk factor for functional disability in the selected studies $6,7,9,21,23,27,28,29,30,32$, present in studies that stratified by gender, and in those whose analyses did not evaluate gender. Among the socioeconomic factors, lack of schooling 6,32 and living in rental housing 6,33 were risk factors for incidence of functional disability, regardless of gender.

Table 2

Incidence of functional disability in the elderly according to gender in analyses of functional disability measure (N = 30$)$ in 21 selected studies.

\begin{tabular}{|c|c|c|c|}
\hline \multirow[t]{2}{*}{ Measures of functional disability } & \multicolumn{3}{|c|}{ Incidence } \\
\hline & Higher in women & Higher in men & No difference between genders \\
\hline Basic activities of daily living & $\begin{array}{l}\text { Beckett at al. } 5 \\
\text { Dunlop et al. } 22\end{array}$ & & $\begin{array}{l}\text { Strawbridge et al. 8; Bruce et al. 21; Moritz et al. 28; } \\
\text { Ferucci et al. 24; Peek \& Coward 30; Avlund et al. } 33 \text {; } \\
\text { Dunlop et al. 23; Gill et al. 25; Chiu et al. } 32 \text {; } \\
\text { Hardy et al. 26; Murtagh \& Hubert 29; Jagger et al. } 31\end{array}$ \\
\hline Instrumental activities of daily living & Peek \& Coward 30 & & Murtagh \& Hubert 29; Chiu et al. 32 \\
\hline Mobility & $\begin{array}{l}\text { Beckett at al. 5; Leveille et al. } 4 \text {; } \\
\text { Avlund et al. } 34 \text {; Nilsson et al. } 35\end{array}$ & & $\begin{array}{c}\text { Melzer et al. 27; Strawbridge et al. 8; } \\
\text { Murtagh \& Hubert 29; Avlund et al. 33; } \\
\text { Oman et al. } 7\end{array}$ \\
\hline \multicolumn{4}{|l|}{ Associations } \\
\hline $\begin{array}{l}\text { Basic activities of daily living + } \\
\text { Instrumental activities } \\
\text { of daily living }\end{array}$ & & & Peek \& Coward 30 \\
\hline $\begin{array}{l}\text { Basic activities of daily living + } \\
\text { Instrumental activities } \\
\text { of daily living + Mobility }\end{array}$ & Tas et al. 9 & & \\
\hline $\begin{array}{l}\text { Basic activities of daily living }+ \\
\text { Mobility }\end{array}$ & & Grundy \& Glaser 6 & \\
\hline
\end{tabular}


Table 3

Incidence of functional disability in the elderly according to gender and adjustment of analyses ( $N=30)$ in 21 selected studies.

\begin{tabular}{|c|c|c|c|}
\hline $\begin{array}{l}\text { Incidence of } \\
\text { functional } \\
\text { disability }\end{array}$ & Measure of functional disability & Multivariate analysis & Crude analysis \\
\hline \multirow[t]{4}{*}{ Higher in women } & Basic activities of daily living & & Beckett at al. 5; Dunlop et al. 22 \\
\hline & Instrumental activities of daily living & Peek \& Coward 30 & \\
\hline & Mobility & & $\begin{array}{l}\text { Beckett et al. 5; Leveille et al. } 4 \text {; } \\
\text { Avlund et al. } 34 \text {; Nilsson et al. } 35\end{array}$ \\
\hline & Basic activities of daily living + Mobility & & Tas et al. 9 \\
\hline Higher in men & Basic activities of daily living + Mobility & Grundy \& Glaser 6 & \\
\hline \multirow[t]{7}{*}{$\begin{array}{l}\text { No difference } \\
\text { between genders }\end{array}$} & Basic activities of daily living & $\begin{array}{c}\text { Bruce et al. 21; Moritz et al. } 28 ; \\
\text { Peek \& Coward } 30 ; \text { Avlund et al. } 33 \text {; } \\
\text { Dunlop et al. } 23 \text {; Gill et al. } 25 ; \\
\text { Chiu et al. } 32 \text {; Hardy et al. } 26 ; \\
\text { Murtagh \& Hubert } 29\end{array}$ & $\begin{array}{c}\text { Stawbridge et al. } 8 \text {; Ferucci et al. } 24 \text {; } \\
\text { Jagger et al. } 31\end{array}$ \\
\hline & Instrumental activities of daily living & Murtagh \& Hubert 29; Chiu et al. 32 & \\
\hline & Mobility & Melzer et al. 27 & Strawbridge et al. 8 \\
\hline & Mobility & Murtagh \& Hubert 29 & \\
\hline & Mobility & Avlund et al. 33 & \\
\hline & Mobility & Oman et al. 7 & \\
\hline & $\begin{array}{l}\text { Basic activities of daily living + } \\
\text { Instrumental activities of daily living }\end{array}$ & Peek \& Coward 30 & \\
\hline
\end{tabular}

Chronic conditions (stroke, arthritis, cancer, heart disease, chronic lung disease, obesity, hip fracture, and systemic arterial hypertension) were a risk factor for functional disability, regardless of gender 7,30. Diabetes was a risk factor for functional disability according to two studies, regardless of gender 23,32. Arthritis was a risk factor for functional disability in three studies: two that did not evaluate gender as a predictor of functional disability 26,32 and one study only in women 9 . Visual impairment was a risk factor for functional disability in two studies 7,23, regardless of gender. Body mass index (BMI) greater than $25 \mathrm{~kg} / \mathrm{m}^{2}$ was a risk factor for incidence of functional disability in both genders according to one study 9 , and BMI greater than $26 \mathrm{~kg} / \mathrm{m}^{2}$ was a risk factor for incidence of functional disability in another study, regardless of gender 7 . Poor self-rated health was a risk factor for incidence of functional disability in both genders in one study ${ }^{9}$ and in another study that did not adjust for gender 6 . Cognitive deficit was a predictor of incidence of functional disability in both genders in one study 28 , in women in another study 9 , and in two studies that did not evaluate gender as a risk factor 7,33. Depression was a predictor of incidence of functional disability in both genders according to two studies 9,21 and according to two other studies that did not evaluate gender as a risk factor 7,26 . Slow gait, defined as taking more than ten seconds to walk approximately three meters, increased the likelihood of incidence of functional disability in two studies that did not adjust for gender 25,26. Sedentary lifestyle increased the risk of incidence of functional disability in two studies 26,33 that did not evaluate gender in their analyses. Tiredness while performing activities of daily living increased the likelihood of functional disability in both genders in one study 34 and in another study that did not evaluate gender as a predictor of functional disability 33. Limited diversity in social relations increased the likelihood of functional disability in both genders in three studies 28,34 and in one study that did not evaluate gender as a risk factor for functional disability 33 . 
Distribution of risk factors for functional disability in the elderly in the 21 selected studies, according to gender.

\begin{tabular}{|c|c|c|c|}
\hline \multirow[t]{2}{*}{ Risk factors } & \multicolumn{3}{|c|}{ Incidence of functional disability } \\
\hline & Women & Men & Gender independent \\
\hline \multicolumn{4}{|l|}{ Socio-demographic } \\
\hline Age & $\begin{array}{l}\text { Bruce et al. } 21 \text { (Basic activities of daily } \\
\text { living); Moritz et al. } 28 \text { (Basic activities of } \\
\text { daily living); Melzer et al. } 27 \text { (Mobility); } \\
\text { Tas et al. } 9 \text { (Basic activities of daily living } \\
\text { + Mobility); Murtagh \& Hubert } 29 \text { (Basic } \\
\text { activities of daily living + Instrumental } \\
\text { activities of daily living + Mobility) }\end{array}$ & $\begin{array}{l}\text { Moritz et al. } 28 \text { (Basic } \\
\text { activities of daily } \\
\text { living); Melzer et al. } 27 \\
\text { (Mobility); Tas et al. } 9 \\
\text { (Basic activities of daily } \\
\quad \text { living + Mobility) }\end{array}$ & $\begin{array}{c}\text { Oman et al. } 7 \text { (Mobility); Peek \& Coward } 30 \text { (Basic activities } \\
\text { of daily living + Instrumental activities of daily living); } \\
\text { Grundy \& Glaser } 6 \text { (Basic activities of daily living + } \\
\text { Mobility); Dunlop et al. } 23 \text { (Basic activities of daily living); } \\
\text { Chiu et al. } 32 \text { (Basic activities of daily living + Instrumental } \\
\text { activities of daily living) }\end{array}$ \\
\hline Lack of schooling & & & $\begin{array}{c}\text { Grundy \& Glaser } 6 \text { (Basic activities of daily living + } \\
\text { Instrumental activities of daily living + Mobility); Chiu } \\
\text { et al. } 32 \text { (Basic activities of daily living + Instrumental } \\
\text { activities of daily living) }\end{array}$ \\
\hline Rental housing & & & $\begin{array}{c}\text { Avlund et al. } 33 \text { (Mobility); Grundy \& Glaser } 6 \text { (Basic } \\
\text { activities of daily living + Instrumental activities of daily } \\
\text { living + Mobility) }\end{array}$ \\
\hline \multicolumn{4}{|l|}{ Health conditions } \\
\hline $\begin{array}{l}\text { Chronic } \\
\text { conditions }\end{array}$ & & & $\begin{array}{c}\text { Oman et al. } 7 \text { (Mobility); Peek \& Coward } 30 \text { (Basic activities } \\
\text { of daily living) }\end{array}$ \\
\hline Diabetes & & & $\begin{array}{c}\text { Chiu et al. } 32 \text { (Basic activities of daily living + Instrumental } \\
\text { activities of daily living); Dunlop et al. } 23 \text { (Basic activities } \\
\text { of daily living) }\end{array}$ \\
\hline Arthritis & $\begin{array}{c}\text { Tas et al. } 9 \text { (Basic activities of daily living } \\
+ \text { Mobility) }\end{array}$ & & $\begin{array}{c}\text { Chiu et al. } 32 \text { (Basic activities of daily living); Hardy et al. } 26 \\
\text { (Basic activities of daily living) }\end{array}$ \\
\hline Visual impairment & & & $\begin{array}{c}\text { Oman et al. } 7 \text { (Mobility); Dunlop et al. } 23 \text { (Basic activities } \\
\text { of daily living) }\end{array}$ \\
\hline $\mathrm{BMI}>25 \mathrm{~kg} / \mathrm{m}^{2}$ & $\begin{array}{c}\text { Tas et al. } 9 \text { (Basic activities of daily living } \\
+ \text { Mobility) }\end{array}$ & $\begin{array}{l}\text { Tas et al. } 9 \text { (Basic } \\
\text { activities of daily living } \\
\quad+\text { Mobility) }\end{array}$ & \\
\hline $\mathrm{BMI}>26 \mathrm{~kg} / \mathrm{m}^{2}$ & & & Oman et al. 7 (Mobility) \\
\hline $\begin{array}{l}\text { Poor self- } \\
\text { perceived health }\end{array}$ & $\begin{array}{c}\text { Tas et al. } 9 \text { (Basic activities of daily living } \\
+ \text { Mobility) }\end{array}$ & $\begin{array}{l}\text { Tas et al. } 9 \text { (Basic } \\
\text { activities of daily living } \\
+ \text { Mobility) }\end{array}$ & $\begin{array}{l}\text { Grundy \& Glaser } 6 \text { (Basic activities of daily living + } \\
\text { Instrumental activities of daily living + Mobility) }\end{array}$ \\
\hline $\begin{array}{l}\text { Poor cognitive } \\
\text { function }\end{array}$ & $\begin{array}{l}\text { Moritz et al. } 28 \text { (Basic activities of daily } \\
\text { living); Tas et al. } 9 \text { (Basic activities of daily } \\
\text { living + Mobility) }\end{array}$ & $\begin{array}{l}\text { Moritz et al. } 28 \text { (Basic } \\
\text { activities of daily living) }\end{array}$ & Avlund et al. 33 (Mobility); Oman et al. 7 (Mobility) \\
\hline Depression & $\begin{array}{c}\text { Tas et al. } 9 \text { (Basic activities of daily } \\
\text { living + Mobility); Bruce et al. } 21 \text { (Basic } \\
\text { activities of daily living) }\end{array}$ & $\begin{array}{l}\text { Tas et al. } 9 \text { (Basic } \\
\text { activities of daily living } \\
+ \text { Mobility); Bruce et } \\
\text { al. } 21 \text { (Basic activities of } \\
\text { daily living) }\end{array}$ & $\begin{array}{c}\text { Oman et al. } 7 \text { (Mobility); Hardy et al. } 26 \text { (Basic activities of } \\
\text { daily living) }\end{array}$ \\
\hline Slow gait * & & & $\begin{array}{c}\text { Gill et al. } 25 \text { (Basic activities of daily living); Hardy et al. } 26 \\
\text { (Basic activities of daily living) }\end{array}$ \\
\hline Sedentary living & & & $\begin{array}{c}\text { Hardy et al. } 26 \text { (Basic activities of daily living); Avlund et al. } \\
33 \text { (Basic activities of daily living) }\end{array}$ \\
\hline $\begin{array}{l}\text { Tiredness during } \\
\text { physical activities }\end{array}$ & Avlund et al. 34 (Mobility) & $\begin{array}{l}\text { Avlund et al. } 34 \\
\text { (Mobility) }\end{array}$ & Avlund et al. 33 (Basic activities of daily living + Mobility) \\
\hline \multicolumn{4}{|l|}{ Social relations } \\
\hline $\begin{array}{l}\text { Little diversity in } \\
\text { social relations }\end{array}$ & $\begin{array}{l}\text { Moritz et al. } 28 \text { (Basic activities of daily } \\
\text { living); Avlund et al. } 34 \text { (Mobility) }\end{array}$ & $\begin{array}{l}\text { Moritz et al. } 28 \text { (Basic } \\
\text { activities of daily } \\
\text { living); Avlund et al. } 34 \\
\text { (Mobility) }\end{array}$ & Avlund et al. 33 (Basic activities of daily living + Mobility) \\
\hline
\end{tabular}

* Takes more than 10 seconds to walk approximately three meters. 


\section{Discussion}

The diversity of instruments used to measure functional disability, study populations, followup period, number of interviews, and data analysis methods hindered the comparison of results between the selected studies. Nevertheless, according to this review, regardless of the measure adopted, the incidence of functional disability was higher in women in the majority of the studies that used bivariate analysis or adjustment for one or two factors, while there was no difference between the genders in the incidence of functional disability when adjusting for socioeconomic and health conditions and social relations. A previous review study of risk factors for functional disability 36 had already observed that two studies that adjusted the analyses for chronic health conditions 37,38 found a similar onset of functional disability between the genders.

\section{Analyses with different adjustments in studies with the same cohort of elderly}

Using data from the EPESE study (Established Populations for Epidemiologic Study of the Elderly), Leveille et al. ${ }^{4}$, in an analysis stratified by sex and adjusted for age only, observed higher incidence of mobility disability in women. Using data from the same cohort, Melzer et al. 27 found that by stratifying for schooling, the incidence of mobility disability was higher in the group with less schooling (0-7 years), making the risk of functional disability similar between men and women.

Dunlop et al. 22, using data from LSOA (Longitudinal Study of Aging), in an analysis of incidence of functional disability in basic activities of daily living, adjusting for age and schooling, observed higher incidence of functional disability in women. In data from the same cohort, Dunlop et al. ${ }^{23}$, without adjusting for chronic health conditions (arthritis, cancer, cardiovascular diseases, diabetes, hearing impairment, obesity, osteoporosis, and visual impairment), found similar incidence of functional disability in basic activities of daily living in men and women.

By using data from the same cohort, these studies allow ruling out the hypothesis that population differences could explain the differential effect of gender on functional disability. Meanwhile, these studies confirmed that the studies' variability on the effect of gender on functional disability in the elderly is due to the indicators for which the analyses are adjusted.
Adjusted analyses that found a difference between genders in the incidence of functional disability

Only two of the studies that conducted multivariate analyses showed different incidences between genders. Methodological issues may explain the disparity between results of these studies and others that adjusted for various factors. Grundy \& Glaser 6 found higher incidence of functional disability in basic activities of daily living and mobility in men in a study that used an instrument that measures less severe limitations than the majority of studies, facilitating the perception of functional disability by men, and that evaluates hearing loss which usually has higher incidence and prevalence in men, in addition to not being included in the traditional instruments that measure functional disability 39,40 . Peek \& Coward 30 observed higher incidence of functional disability in instrumental activities of daily living in women in a study whose sample consisted of elderly individuals with arthritis. The instrument that measures instrumental activities of daily living uses some questions like doing housework, preparing meals, and grocery shopping, which are considered "women's work", and which lead to a differential assessment between genders 41 . The study showed the highest proportion of women among the selected studies (79\%), since arthritis is more prevalent in women 42,43 .

\section{$\underline{\text { Risk factors for functional disability }}$}

Increasing age was the most frequent risk factor for functional disability among the selected studies, independently of gender, which had already been observed in a previous review study 36 and proved the trend towards functional decline with increasing age in the elderly.

Among the socioeconomic factors, low schooling and living in rental housing increased the risk of functional disability, regardless of gender, showing that elderly individuals in worse socioeconomic conditions are more vulnerable to incidence of functional disability, as previously observed in other studies 44,45,46,47.

Among the health indicators, chronic health conditions increased the risk of incidence of functional disability, regardless of gender, as observed in other studies $37,48,49$. Considering that only one study evaluated arthritis as an independent variable in a gender-stratified analysis, it is not possible to rule out that arthritis may represent a greater risk of functional disability in women, as observed in previous studies 42,43 .

The higher risk of functional disability in elderly individuals with limited diversity in their 
social relations highlights the importance of social ties for their health 50 .

Despite the small number of studies that used gender-stratified analyses, except for arthritis, the predictors of functional disability are the same in men and women.

\section{Conclusions}

According to this review, gender is not a risk factor for incidence of functional disability in the elderly. Rather, age, socioeconomic and health conditions, and social relations determine the incidence of functional disability. Prevention of functional disability in men and women should act on the risk factors that are amenable to intervention, like sedentary lifestyle and limited diversity of social relations. In relation to these factors, measures like physical activity and maintaining social ties should be encouraged, regardless of gender.

The results of this review were reinforced by the opportunity to compare findings from studies that used crude analyses 4,22 with others that used adjusted analyses 23,27 based on the same cohort's database. Studies that used crude analyses observed a different incidence of functional disability between the genders in the elderly, while studies that adjusted their analyses for socio-demographic, socioeconomic, and health factors observed no difference between the genders in the incidence of functional disability. Methodological difficulties in this review indicate the need for standardized measures of functional disability to allow comparability of the studies' results and taking precautions starting with the study's initial planning in order to prevent losses to follow-up, thus avoiding analyses from being performed with data from the healthiest individuals. Equally important is to avoid dichotomization of functional disability when the study instrument contains more than one question on functional capacity. Dichotomization inappropriately simplifies the information on functional capacity, leading to classification errors and false conclusions. The use of multiple measures of functional disability allows better capturing of subtle differences in functional capacity in the elderly. Another observation in this review study is that data collection instruments should draft the questions on functional disability in the present tense, since hypothetical questions can induce answers that are influenced by cultural factors and family arrangements.

\section{Limitations}

Except for one article 32 , the studies selected in this review were conducted in developed countries, which limits extrapolation of the findings to developing countries, where there is greater social and economic inequality, with probable impact on functional disability in the elderly.

The possibility of publishing bias cannot be ruled out, since only one study showed higher incidence of functional disability in men.

Measures of functional disability were collected through self-reported data, except in one of the studies 7 . However, besides the fact that the validity of self-reported (as compared to observed) data has already been proven in both genders 51 , this issue does not compromise comparison of the studies. 


\section{Resumo}

Esta revisão sistemática teve por objetivo avaliar o efeito do gênero sobre a incidência de incapacidade funcional em idosos. A pesquisa de publicações nas bases eletrônicas de dados MEDLINE, EMBASE e ProQuest no período de janeiro de 1990 a março de 2008 identificou 879 publicações, das quais foram selecionados 21 estudos de coortes que avaliaram gênero como variável independente e incidência de incapacidade funcional em idosos como desfecho. A revisão dos estudos selecionados demonstrou que após ajuste para indicadores sócio-econômicos, de saúde e de relações sociais a incidência de incapacidade funcional foi semelhante entre os gêneros. Os principais fatores de risco para incapacidade funcional, independente do gênero dos idosos, foram: falta de escolaridade, moradia alugada, doenças crônicas, diabetes, déficit visual, índice de massa corporal acima de 25, autopercepção de saúde como não boa, déficit cognitivo, depressão, marcha lenta, sedentarismo, cansaço ao realizar as atividades diárias e pouca diversidade nas relações sociais.

Saúde do Portador de Incapacidade; Idoso Fragilizado; Gênero e Saúde

\section{Contributors}

M. A. P. Rodrigues participated in all stages of the study, including the planning, literature search, study selection, evaluation of studies, and final elaboration of the article. L. A. Facchini participated in the planning, evaluation of selected studies, and final revision. E. Thumé participated in the evaluation of the selected studies and elaboration of the article. F. Maia participated in the literature search, study selection, and elaboration of the article.

\section{References}

1 Guralnik JM, Fried LP, Salive ME. Disability as a public health outcome in the aging population. Annu Rev Public Health 1996; 17:25-46.

2. Newman AB, Brach JS. Gender gap in longevity and disability in older persons. Epidemiol Rev 2001; 23:343-50

3. Crimmins EM. Mixed trends in population health among older adults. J Gerontol B Psychol Sci Soc Sci 1996; 51:S223-5.

4. Leveille SG, Penninx BW, Melzer D, Izmirlian G, Guralnik JM. Sex differences in the prevalence of mobility disability in old age: the dynamics of incidence, recovery, and mortality. J Gerontol B Psychol Sci Soc Sci 2000; 55:S41-50.
5. Beckett LA, Brock DB, Lemke JH, Mendes de Leon CF, Guralnik JM, Fillenbaum GG, et al. Analysis of change in self-reported physical function among older persons in four population studies. Am J Epidemiol 1996; 143:766-78.

6. Grundy E, Glaser K. Socio-demographic differences in the onset and progression of disability in early old age: a longitudinal study. Age Ageing 2000; 29:149-57.

7. Oman D, Reed D, Ferrara A. Do elderly women have more physical disability than men do? Am J Epidemiol 1999; 150:834-42. 
8. Strawbridge WJ, Kaplan GA, Camacho T, Cohen RD. The dynamics of disability and functional change in an elderly cohort: results from the Alameda County Study. J Am Geriatr Soc 1992; 40:799-806.

9. Tas U, Verhagen AP, Bierma-Zeinstra SM, Hofman A, Odding E, Pols HA, et al. Incidence and risk factors of disability in the elderly: the Rotterdam Study. Prev Med 2007; 44:272-8.

10. Alves LC, Leite IC, Machado CJ. Conceituando e mensurando a incapacidade funcional da população idosa. Uma revisão de literatura. Ciênc Saúde Coletiva 2008; 13:1199-207.

11. Nagi S. An epidemiology of disability among adults in the United States. Milbank Mem Fund Q 1976; 54:439-68.

12. World Health Organization. Towards a common language for functioning, disability and health: ICF. The International Classification of Functioning, Disability and Health. Geneva: World Health Organization; 2002.

13. Verbrugge LM, Jette AM. The disablement process. Soc Sci Med 1994; 38:1-14.

14. Katz S, Akpom CA. 12. Index of ADL. Med Care 1976; 14(5 Suppl):116-8.

15. Lawton MP, Brody EM. Assessment of older people: self-maintaining and instrumental activities of daily living. Gerontologist 1969; 9:179-86.

16. Rosow I, Breslau N. A Guttman health scale for the aged. J Gerontol 1966; 21:556-9.

17. Avlund K, Kreiner S, Schultz-Larsen K. Functional ability scales for the elderly: a validation study. Eur J Public Health 1996; 6:35-42.

18. Fries JF, Spitz PW, Young DY. The dimensions of health outcomes: the health assessment questionnaire, disability and pain scales. J Rheumatol 1982; 9:789-93.

19. Martin J, Meltzer H, Elliot D. The prevalence of disability among adults. London: Her Majesty's Stationery Office; 1988.

20. Downs SH, Black N. The feasibility of creating a checklist for the assessment of the methodological quality both of randomised and non-randomised studies of health care interventions. J Epidemiol Community Health 1998; 52:377-84.

21. Bruce ML, Seeman TE, Merrill SS, Blazer DG. The impact of depressive symptomatology on physical disability: MacArthur Studies of Successful Aging. Am J Public Health 1994; 84:1796-9.

22. Dunlop DD, Hughes SL, Manheim LM. Disability in activities of daily living: patterns of change and a hierarchy of disability. Am J Public Health 1997; 87:378-83.

23. Dunlop DD, Manheim LM, Sohn MW, Liu X, Chang RW. Incidence of functional limitation in older adults: the impact of gender, race, and chronic conditions. Arch Phys Med Rehabil 2002; 83:964-71.

24. Ferrucci L, Guralnik JM, Simonsick E, Salive ME, Corti C, Langlois J. Progressive versus catastrophic disability: a longitudinal view of the disablement process. J Gerontol A Biol Sci Med Sci 1996; 51:M123-30.

25. Gill TM, Allore H, Holford TR, Guo Z. The development of insidious disability in activities of daily living among community-living older persons. Am J Med 2004; 117:484-91.
26. Hardy SE, Allore HG, Guo Z, Gill TM. Explaining the effect of gender on functional transitions in older persons. Gerontology 2008; 54:79-86.

27. Melzer D, Izmirlian G, Leveille SG, Guralnik JM. Educational differences in the prevalence of mobility disability in old age: the dynamics of incidence, mortality, and recovery. J Gerontol B Psychol Sci Soc Sci 2001; 56:S294-301.

28. Moritz DJ, Kasl SV, Berkman LF. Cognitive functioning and the incidence of limitations in activities of daily living in an elderly community sample. Am J Epidemiol 1995; 141:41-9.

29. Murtagh KN, Hubert HB. Gender differences in physical disability among an elderly cohort. Am J Public Health 2004; 94:1406-11.

30. Peek K, Coward RT. Gender differences in the risk of developing disability among older adults with arthritis. J Aging Health 1999; 11:131-50.

31. Jagger C, Arthur AJ, Spiers NA, Clarke M. Patterns of onset of disability in activities of daily living with age. J Am Geriatr Soc 2001; 49:404-9.

32. Chiu HC, Mau LW, Tasi WL. Chronic medical conditions as predictors of functional disability in an older population in Taiwan. Aust J Ageing 2004; 23:19-24.

33. Avlund K, Damsgaard MT, Sakari-Rantala R, Laukkanen P, Schroll M. Tiredness in daily activities among nondisabled old people as determinant of onset of disability. J Clin Epidemiol 2002; 55: 965-73.

34. Avlund K, Lund R, Holstein BE, Due P. Social relations as determinant of onset of disability in aging. Arch Gerontol Geriatr 2004; 38:85-99.

35. Nilsson CJ, Lund R, Avlund K. Cohabitation status and onset of disability among older Danes: is social participation a possible mediator? J Aging Health 2008; 20:235-53.

36. Stuck AE, Walthert JM, Nikolaus T, Bula CJ, Hohmann C, Beck JC. Risk factors for functional status decline in community-living elderly people: a systematic literature review. Soc Sci Med 1999; 48: 445-69.

37. Boult C, Kane RL, Louis TA, Boult L, McCaffrey D. Chronic conditions that lead to functional limitation in the elderly. J Gerontol 1994; 49:M28-36.

38. Guralnik JM, Kaplan GA. Predictors of healthy aging: prospective evidence from the Alameda County Study. Am J Public Health 1989; 79:703-8.

39. Cruickshanks KJ, Wiley TL, Tweed TS, Klein BE, Klein R, Mares-Perlman JA, et al. Prevalence of hearing loss in older adults in Beaver Dam, Wisconsin. The Epidemiology of Hearing Loss Study. Am J Epidemiol 1998; 148:879-86.

40. Helzner EP, Cauley JA, Pratt SR, Wisniewski SR, Zmuda JM, Talbott EO, et al. Race and sex differences in age-related hearing loss: the Health, Aging and Body Composition Study. J Am Geriatr Soc 2005; 53:2119-27.

41. Allen SM, Mor V, Raveis V, Houts P. Measurement of need for assistance with daily activities: quantifying the influence of gender roles. J Gerontol 1993; 48:S204-11.

42. Hootman JM, Sniezek JE, Helmick CG. Women and arthritis: burden, impact and prevention programs. JWomens Gend Based Med 2002; 11:407-16. 
43. Theis KA, Helmick CG, Hootman JM. Arthritis burden and impact are greater among U.S. women than men: intervention opportunities. J Womens Health (Larchmt) 2007; 16:441-53.

44. Maddox GL, Clark DO. Trajectories of functional impairment in later life. J Health Soc Behav 1992; 33:114-25.

45. Coppin AK, Ferrucci L, Lauretani F, Phillips C, Chang M, Bandinelli S, et al. Low socioeconomic status and disability in old age: evidence from the InChianti study for the mediating role of physiological impairments. J Gerontol A Biol Sci Med Sci 2006; 61:86-91.

46. Amaducci L, Maggi S, Langlois J, Minicuci N, Baldereschi M, Di Carlo A, et al. Education and the risk of physical disability and mortality among men and women aged 65 to 84: the Italian Longitudinal Study on Aging. J Gerontol A Biol Sci Med Sci 1998; 53:M484-90.
47. Adamson J, Hunt K, Ebrahim S. Socioeconomic position, occupational exposures, and gender: the relation with locomotor disability in early old age. J Epidemiol Community Health 2003; 57:453-5.

48. Rudberg MA, Parzen MI, Leonard LA, Cassel CK. Functional limitation pathways and transitions in community-dwelling older persons. Gerontologist 1996; 36:430-40.

49. Woo J, Ho SC, Yu LM, Lau J, Yuen YK. Impact of chronic diseases on functional limitations in elderly Chinese aged 70 years and over: a cross-sectional and longitudinal survey. J Gerontol A Biol Sci Med Sci 1998; 53:M102-6.

50. Verbrugge LM, Reoma JM, Gruber-Baldini AL. Short-term dynamics of disability and well-being. J Health Soc Behav 1994; 35:97-117.

51. Merrill SS, Seeman TE, Kasl SV, Berkman LF. Gender differences in the comparison of self-reported disability and performance measures. J Gerontol A Biol Sci Med Sci 1997; 52:M19-26.

Submitted on 17/Mar/2009

Final version resubmitted on 07/Jul/2009

Approved on 13/Jul/2009 